\title{
Türkmen Atasözlerinde Meslek Adları
}

\author{
Levent DOĞAN ${ }^{1}$
}

\section{$\ddot{O}_{z}$}

Türkmen sözlü edebiyatında atasözleri nakıl olarak adlandırılır. Tarihin derinliklerinden günümüze süzülen atasözleri toplumların sosyo-kültürel hayatının bir görüntüsü niteliğindedir. Her biri ustaca ve bilgece söylenmiş olan bu sözlerde toplumun içinden pek çok kavram ve ayrıntı bir konu çevresinde anlatıma incelikle yerleştirilerek işlenmiştir. Bu yüzden dilin manevi varlıkları sayılan atasözleri bir milleti anlamak, görmek ve tanımak noktasında üstlendikleri rol açısından çok önemlidirler. Mesleklerin insan hayatında önemli bir yeri vardır. Ekonomik faaliyetler kapsamında bulunan meslekler insanoğlunun varoluşuyla ortaya çıkmış ve insanların gereksinimleri doğrultusunda günümüze kadar çeşitlenerek gelmiştir. Bu araştırmada Oğuz grubu (Güney-Batı) Türk lehçelerinin doğu kolunda yer alan Türkmen Türkçesinin atasözlerinden hareketle Türkmenlere özgü meslekler ortaya konulmuştur. Çalışmada atasözleri dışında Türkmence sözlüklerde geçen meslek adlarına da yer verilmiş ve çok sayıda mesleğe ulaşılmıştır. Ayrıca Türkmen atasözlerinden elde edilen meslek adları ile Eski Türkçe Dönemi, Dîvânu Lugâti’t-Türk ve Kutadgu Bilig'de bulunan meslek adları arasında bir kısım benzer sözcüklere rastlanmıștır.

Anahtar Kelimeler: Türkmen Türkçesi, Atasözleri, Meslek Adları

\section{Turkmen Proverbs Related to Occupation}

\section{Abstract}

In Turkmen oral literature proverbs are known as "nakil". Proverbs reflects socio-cultural life of the people from ancient time till nowadays and is used skillfully and wisely. Proverbs are considered to be spiritual beings of language; therefore, they are very important in terms of the role they play in understanding and recognizing nation. Proverbs related to the occupation play great role in human life. Occupations which are used in economic appeared together with existence of human beings and have been diversified to the present day in accordance with the needs of people. Turkmen Turkish is the eastern branch of the Turkish dialects of the Oghuz group (South-West) and the study is based on the proverbs connected to occupations of Turkmen Turkish. Apart from proverbs the study covers the words taken from Turkmen dictionaries with meaning of profession. Beside this some similarities were found between Turkmen proverbs standing for profession and the names of professions from the Old Turkish Period, Dîvânu Lugâti't-Türk and Kutadgu Bilig.

Key Words: Turkmen Turkish, Proverbs, Profession Names

Atıf İçin / Please Cite As:

Doğan, L. (2020). Türkmen atasözlerinde meslek adları. Manas Sosyal Arastırmalar Dergisi, 9(2), 648-664.

Geliş Tarihi / Received Date: 30.03.2019

Kabul Tarihi / Accepted Date: 03.06.2019

\footnotetext{
${ }^{1}$ Dr. Öğr. Üyesi - Trakya Üniversitesi Edebiyat Fakültesi, ldogan@trakya.edu.tr ORCID: 0000-0002-0538-4002
} 


\section{Giriş}

Her ulusun söz varlığında atasözlerinin ayrı bir yeri bulunmaktadır. Atasözleri; bir toplumun geçmişini, kültür yapısını, yaşam biçimini, gelenek-göreneklerini ortaya koyan özlü anlatımlardır. Bu bakımdan ait olduğu toplum hakkında geniş bilgiler sunar. Bununla birlikte sözlü geleneğin bir ürünü olan atasözleri, bünyesinde barındırdıkları zengin malzeme yönüyle meydana geldikleri toplumun farklı alanlarına ilişkin pek çok kavramın görülmesinde önemli dil yapıları sayılır.

Atasözlerine ilişkin diğer özellikler bu terim üzerine yapılan tanım ve açıklamalardan belirlenebilmektedir:

Ömer Asım Aksoy (2017, s. 13), atasözleri için "Toplumbilim, rubbilim, eğitbilim, ekonomi, felsefe, tarih, ablak, folklor gibi birçok konular ilgilendiren ve bircok yönlerden inceleme konusu edilmeye değer ulusal varllklar." diyerek atasözlerinin diğer alanlarla olan ilişkisine dikkat çekmiştir.

Dehri Dilçin (2000, s. 15) ise atasözlerini "Beşser cemiyetiyle beraber doğmuş, onunla birlikte oba, boy ve oymak. olarak asirlarca göşebe hayatı yașamıs ve nihayet gelisip özleşerek de ulusal hâle yülkselmiş, medenîleşmis törelerdir." biçiminde tanımlamıştır. Dilçin'in tanımında ilk insanların yaşama biçimi olan göçebelik zamanında atasözlerinin varlığına değinmesi bu hikmet dolu sözlerin çok eski ve uzun bir geçmişe sahip olduğunu göstermektedir.

Celal Beydili (2004, s. 4), atasözlerine "Cilt cilt kitaplar dolusu mana ve hikmeti özüne siğdıran-bu balk

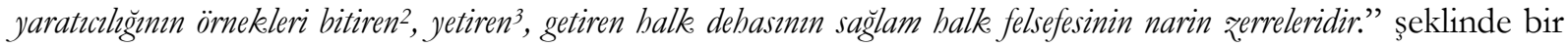
tanımlama getirmiştir.

Mehmet Kilıç (1996, s. 14), atasözlerine mahsus özellikleri; "kıssa sözde genis mana ifade etmek, etkileyicilik, derin düsü̈ne, akıl-mantık, millililik ve mecaz̨i anlamlllke" olarak sıralamıştır.

Türkmen Türkçesi atasözlerine bakıldığında şekli, sözdizimi, özellikleri, konuları ve anlamları bakımından Türkiye Türkçesi atasözleriyle büyük benzerlikler gösterir. Hatta bazı atasözleri Türkiye Türkçesiyle özdeştir. Meslekleri ele aldığımız Türkmen Türkçesi atasözlerinden ortak veya benzer olanlara birkaç örnek şu şekildedir: TkmT Avç näge al bilse, av hem şonça yol biler. "Avcı ne kadar hile bilirse, av da o kadar yol bilir." TT Avo ne kadar hile bilirse, ayı o kadar yol bilir. TkmT Copan köp bolsa, toklusı haram öler. "Çobanı çok olursa, toklusu murdar ölür." TT Çoban çok olanda koyun murdar ölür. TkmT Bir akmagiñ guya atan daşım on dervüs çlkarıp bilmez: "Bir ahmağın attığı taşı on derviş çıkaramaz." TT Bir deli kuyuya taş atmış, kırk akıll çıkaramamış. TkmT Gassap tamışına süyek berer. "Kasap tanıdığına kemik verir." TT Kasap anasina da kemik satar. TkmT Geçi tayak iyesi gelse, çopana süykener. "Keçi dayak isterse, çobana sürtünür." TT Eceli gelen keçi çobanın dayağına sürünür. vb. daha birçok örnek bulunmaktadır.

Türkmen halk edebiyatı ürünlerinin en eski örneklerine Dîvânu Lugâti't-Türk'te rastlanır. Örneğin, Divandaki atasözleri hem eserin yazıldığ1 yüzyılda hem de ondan önceki devirlerde söylenen ve bazısı bugün dahi Türkmenler arasında kullanılmaya devam edilen sözlerdir (Kılıç, 1996, s. 1).

Türkmenler oldukça zengin bir folklor hazinesine sahiptir. Bu folklor hazinesi içinde atasözleri, Türkmenler arasında en çok bulanan türlerden biridir (Çınar, 1996, s. 358). Atasözleri, atalarımızın bilgece ve zekice söyledikleri sözler olması yönüyle Türkmenler tarafından anonim halk edebiyatının belki de en önemli ürünleri olarak görülmektedir (Kılıç, 1996, s. 14).

Türkmenlerde atasözlerinin eğitim amaçlı kullanılması bir gelenek hâline gelmiştir. Mehmet Kılıç (1996, s. 14) Türkmenlerin çocuklara nasihat vermede, onların edepli ve itibarlı kişiler olarak yetişmesinde bu nezaket ve görgü kurallarıyla dolu atasözlerine başvurduklarını belirtmektedir.

Türkmen atasözlerinin doğuşu ve gelişimi anonim halk yaratıcilığındaki diğer ürünlerin ortaya çıkışına benzemektedir. Başlangıçta elbette birileri tarafindan söylenmiş olan bu sözler daha sonra halk tarafindan benimsendiği için ilk söyleyenlerin adı sanı zamanla unutulmuştur (K1lıç, 1996, s. 2). Türkmenler, millî benliklerini ve millî değerlerini yansıtan atasözleri dile getirmişlerdir. Onların olup bitmiş olaylarla ilgili görüşleri, bu olaylar karşısında almış oldukları tavırları ve yaşamda önem verdikleri unsurların hepsi bu sözlü anlatım türünde görülmektedir.

\footnotetext{
2 Azr.: bitirmək: "sonuçlamak"

3 Azr.: yetirmək: "ulaştırmak"
} 


\section{Türkmen Atasözlerinde Meslek Adları}

Türkmen halkının günlük yaşamına dair birçok şeyi atasözlerinde bulmak mümkündür. Yaşamın bir parçası olan meslekler de bunlardan birisidir. Bu bağlamda atasözleri Türkmenlere ait meslek adlarının tespitinde yardımcı kaynaklardır.

İlk çağlardan bu yana insanlar hayatını idame ettirebilmek maksadıyla çeşitli ekonomik faaliyetlerde bulunmuşlardır. Buna bağlı olarak geçim kaynakları içinde bulunulan devrin koşullarına göre devamlı bir değişime uğramıştır. Dolayısıyla o günden bugüne farklı birçok meslek ortaya çıkmıştır. Fakat eski zamanların pek çok mesleği günümüzdeki teknolojik gelişmelerin hızla ilerlemesinden etkilenerek kaybolmaya başlamıştır (Tez, 2016, s. 41). Özellikle el emeğine ve ustalığa dayalı meslekler; makineleşmenin artması, kitlesel üretim ve seri tüketim, el işine yatkın çırak bulmanın zorluğu ve el yapımı ürünlere müşteri bulunamaması gibi nedenlerden dolayı zaman içinde yok olup gitmektedir (Tez, 2016, s. 42).

Her ülkede yaygınlık kazanan meslek grupları ülkenin coğrafi konumuna göre değişiklik gösterir. Tüm dünyayla ortak olan bazı meslekler dışında sadece o topluma özgü mesleklerin ortaya çıkışında ülkenin yeryüzü şekilleri başta olmak üzere iklim ve bitki örtüsü, toprak özellikleri ve toplumun ihtiyaçları etkili olmuştur. Bir toplumda yer alan meslek grupları da atasözleri gibi o toplumun siyasi, sosyal, ekonomik ve kültürel yapısına yönelik ipuçları verir.

\section{Yöntem}

Bu çalışmada Türkmen atasözlerinde yer alan meslek adları tespit edilerek ortaya konmuştur. Tespit edilen adlar belli başlıklar altında sınıflandırıldıktan sonra kökenine ulaşılan meslek adının yanında hangi dilden geçtiği gösterilmiştir. Meslek adları sınıflandırılırken Serkan Şen ${ }^{1}$ ve Galip Güner ${ }^{2}$ in konuyla ilgili çalışmalarındaki tasniflerden faydalanılmıştır. Atasözlerinde bulunan meslek adları dışında İlhan Çeneli’nin Türkmen Türkçesi Sözlüğü ile Talat Tekin ve diğerlerinin hazırladığ1 Türkmence-Türkçe Sözlük'te geçen meslek adları da taranmıştır. Ancak bu sözlüklerden ulaşılan meslek adları çalısmada sadece alfabetik bir şekilde sıralanarak gösterilmiş, herhangi bir sınıflamaya ya da köken bakımından değerlendirmeye tabi tutulmamıştır. Ayrıca çalışmada gerek örnek olarak kullanılan atasözlerinde gerekse belirlenen meslek adlarında taranan atasözü kitapları ile sözlüklerdeki şekil ve anlamlara bağlı kalınmıştır.

\section{Bulgular}

Türkmen atasözlerinde meslek anlamina gelen kär ve kesp sözcükleri bulunur. Bunlarla birlikte Türkmence-Türkçe Sözlük'te rastlanılan senet ve bünär de meslek karşllı̆ı kullanılan diğer sözcüklerdir. Yine bu alanla ilintili olarak bahsi geçen sözlükte bünärli (meslek sahibi), bünärlilik (bir meslek sahibi olma) ve işdeş, kärdeş (meslektaş) terimleri yer alır.

Türkmen Türkçesi atasözlerindeki meslek adlarını Eski Türkçe Dönemi, Dîvânu Lugâti’t-Türk ve Kutadgu Bilig'de yer alan meslek adlarıyla karşılaştırdığımızda şekil ve anlam yönünden benzerlik gösteren sözcüklere rastlanmıştır.

avç: abç1, avçı $(\mathrm{ET})>$ avçı, awç1 $(\mathrm{DLT})>\operatorname{awç1}(\mathrm{KB})>\operatorname{avç1}(\mathrm{TkmT})$, ayakkabıcı: etükçi (DLT) > etükçi (KB) > ädikçi (TkmT), balıkg̨: balıkç̧ı (EUTS) > balıkçı (TkmT), bey / efendi: bäg (ET) > beg bēg (DLT) > beg (TkmT), beylik: bäglig (ET) > beglik (DLT) > beglik (TkmT), bilgin / âlim: alim (KB) > alım (TkmT), çoban: çupan ${ }^{4}$ (DLT) > çopan / çofan (TkmT), demirci: tämirci (EUTS) > temürçi (DLT) > temürçi (KB) > demirçi (TkmT), doktor / tabip: ämçi (EUTS) > emçi (DLT) > emçi (KB) > emçi (TkmT), elçi: älçi, ilçi $(\mathrm{ET})>$ ilçi $(\mathrm{KB})>$ ilçi $(\mathrm{TkmT})$, gemici / denizcci: kämici (EUTS) > gämiçi $(\mathrm{TkmT}$ ), han / bükümdar: han (EUTS) > xān (DLT) > han (TkmT), hırsı: og̀n (EUTS) > ogr1 (DLT) > ogr1 (TkmT), brrsı̨̧lk: ogrılık (DLT) > ogurlık, ogrulık (TkmT), kadl: kazı (KB) > kazı (TkmT), kapıcı: kapugçı (KB) > gapıçı (TkmT), kul / köle: hul, kul, kul (ET) > kul (DLT) > kul (KB) > gul (TkmT), küçük tüccar / dükkan sabibi: çergüçi $(\mathrm{KB})>$ cerçi $(\mathrm{TkmT})$, lider / yönetici / amir: başç1 ${ }^{5}(\mathrm{~KB})>$ başç1 $(\mathrm{TkmT})$, nöbetçi / bekçi / mubafıæ: sakç1 $(\mathrm{KB})>$ sakçı $($ TkmT), oyuncu: oyunçı (EUTS) > oyunçı (TkmT), peblivan: böke $(\mathrm{KB})>$ böke

\footnotetext{
1 Şen, S. (2007). Orhon, Uygur ve Karahanl Metinlerindeki Meslekler Bă̆lammnda Eski Türk Kültüü̈ (Doktora Tezi). On Dokuz May1s Üniversitesi, Sosyal Bilimler Enstitüsü, Samsun.

2 Güner, G. (2010). Kıpçak Türkçesindeki Meslek Adları Üzerine İçerik ve Yapı Bakımından Bir Sınıflandırma Denemesi. Turkish Studies. C. 5. S. 3. s. 1416-1448.

${ }^{4}$ DLT'de bu sözcük "köy büyügünün yardımcısı" anlamındadır. DLT, s. 629.

${ }^{5}$ KB'de baş̧̨ kelimesi "rehber" anlamındadır. KB, s. 64.
} 
$(\mathrm{TkmT})$, satıcı / tüccar: satıgçı $(\mathrm{ET})>$ satguçı $(\mathrm{DLT})>\operatorname{satıgç1~}(\mathrm{KB})>$ satıc1 / satuvc1 $(\mathrm{TkmT})$, tercüman: trlmaç (KB) > dilmaç (TkmT), türkücü / ozan / saz, sairi: bahşsi, bakșs ${ }^{6}$ (EUTS) > bagșs (TkmT), ulak: ulag (EUTS) > ulag (DLT) > ulag (TkmT), vezir: vezir $(\mathrm{KB})>$ vezir $($ TkmT)

Aşağıda Türkmence sözlüklerden ${ }^{7}$ derlenen meslek adları sıralanmıştır. Bu sıralamada sözlüklerdeki meslek adlarının yanı sıra belli bir meslekle ilgili unvan adlarına da yer verilmiştir. İlhan Çeneli'nin "Türkmen Türkçesi Sözlügüu” adlı çalsşmasında on yedi ${ }^{8}$ meslek adı belirlenmiştir. Bu on yedi meslek haricinde geri kalan meslekler Talat Tekin ve diğerlerinin ortak hazırladığı Türkmence-Türkçe Sözlük'ten elde edilmiştir.

A: administrator "yönetmen, yönetici", admiral "amiral", advokat "avukat", adyutant "yaver", agaç̧ "marangoz", agent "ajan, casus", agronom "tarım uzmanı, tarımc1, ziraatç1", aktrisa "kadın aktör, kadın oyuncu" aktyor "aktör, oyuncu" aktyorllk "aktörlük, oyunculuk", aragatnaşılkçı "irtibatçı", arbeolog "arkeolog", arbitektor "mimar", arbitektura "mimarlık", alım "âlim, bilgin", aşpez "aşçı", artist "oyuncu, artist", atçapar "atlı, binici", atger "iyi nişanc1, avc1", avç "avc1", avçllk "avc1lık", avtor "yazar, müellif", avtorlı "yazarlık", ayakgap garalaycı "ayakkabı boyacısı", aydıc "anlatan, hikâye eden", aydımçı "türkücü, halk ozanı", ayıplaycı "Savc1", azanç "müezzin".

B: bagșı "türkücü, saz şairi, halk ozanı", baș "bașkan, reis", bașvraç "başhekim", bale artistikası "kadın


batrak "Irgat, işç", batrak ayal "1rgat kadın", bende "bende, kul", bilgir "erbap, ehil; ileriyi gören; kâhin", birca dellalı "borsa simsarı", bokesç "boksçu, boksör", biçimci "makasçı", biçimçi ayal "makasçı kız", biçimçilik "makasç1lık mesleği", birinci rang kapitam "deniz albayı".

C: cadl "büyücülük, sihirbazlık; büyü, sihir", cadgg̈̈y "büyücü, sihirbaz; üfürükçü", cellap "tüccar", cellat "cellat, eziyet eden, zalim", ceñbaz "savaşçı, savaşan", cerçi "küçük tüccar, dükkan sahibi”, cigit "atlı, binici", cogapkër nobatçı "sorumlu nöbetçi."

Ç: çalıc "çalgıc1, müzisyen", çapar "atlı haberci, ulak", çapavul "1. kurye. 2. yağma, çapulculuk", çapavulçllk "yağmacıllk", çapavullık "yağmacıllk", çap̧ı "matbaacı, basımcı", çarbçı "bileyici", çayçı "çaycı", çekimçi "tartıc1, kantar katibi", çelikçi "fiçı yapan ya da satan kimse", çinovnik "memur, bürokrat", çinovniklik "memurluk, memuriyet", çoluk "çoban yamağı", çoluksıllhk "çoban yamaklığı", colukllk "çoban yamaklığı", çopan "çoban", çopançllk "çobanlık", çopanlık "çobanlık", çor "hizmetçi”, çörekçi "ekmekçi".

D: darbaz "cambaz, ip çambazı", darbaz̨cllk "cambazlık mesleği”, dayhan "1. çiftçi; köylü. 2. ırgat, kap1 kulu", dayhan hocalıg "çiftçilik", dayhançılık "1. çiftçilik; köylülük. 2. 1rgatlık, toprak işçiliği", dekan "dekan", dekorator "dekoratör", delegat "delege, temsilci", dellal "tellal, simsar", dellalçllhk "tellallık, simsarlık", dellallık. "tellallı, simsarllk", dellek "berber", deputat "milletvekili", deputatlk "milletvekilliği”, deriç "derici", dermanhana isggäri "eczac1", derñevçi "müfettiş, kontrol memuru; sorgu yargic1, sorgu hakimi", dervez̧eban "kapıc1, bekçi, kapı muhafızı", dervezęci "kaleci", dervüss "derviş", dindarıc "kurtarıcı", diktor "spiker", dilci "dilci, dilbilimci", dilçilik "dilcilik mesleği", dilegçi "1. dilenci. 2. ricacı", dilmaç "tercüman, dilmaç", dilmaçlı "tercümanlık", diñleyci "dinleyici; öğrenci”, direktor "yönetmen, direktör, müdür", direktsiya "yönetmenlik, direktörlük", dirijyor "orkestra şefi", dirijjorlı "orkestra şefliği", divana "dilenci", divanaçllk "dilencilik", dokmaç "dokuma ustas1, dokumacı", dokmaçıllk "dokumacillk", doktor "1. bilim doktoru. 2. doktor, hekim", doktorllk "doktorluk, hekimlik mesleği", doñuzdar "domuz üreticisi", doñuzdarçllk "domuz üreticiliği", dotsent "doçent", dotsentlik "doçentlik", dovarç "koyun yetiștiricisi", dovarçllk "koyun yetiștirimi", diș doktoru "diş hekimi", dramaturg "oyun yazarı, piyes yazarı", dublyor "yedek oyuncu", dükançllk "bakkallık, dükkan işletme", dïyedar "deve yetiştiricisi", düyedarçllk "deve yetiştiriciliği, devecilik", düyekeş "deve sürücüsü, deveci".

Ä: ädikşi "çizmeci, ayakkabıcı”, ädikçilik "çizmecilik, ayakkabıcılık”.

E: ekinçi "ekinci, çiftçi”, ekinçilik "ekincilik, çiftçilik", ekskursovod "Kılavuz, rehber", elektrik "elektrikçi”, enece "çocuk bakıcısı, dadı", eneke "dadı", esger "asker", esgerlik "askerlik", et satı̧ı "kasap", eyerçi "eyerci, eyer ustası".

${ }^{6}$ EUTS'de bahsi, baksı sözcükleri “muallim, öğretmen; ustad; hekim, doktor, tabip” anlamlarına gelmektedir. EUTS, s. 31-32. ${ }^{7}$ Çeneli, İ. (1986). Türkmen Türkçesi Sözlüğü. Türk Dili Araştırmalar Yulluğg-Belleten. C. 26. S. 1982-1983. s. 29-84. ; Tekin, T., ve diğerleri. (1995). Türkmence-Türkşe Sözlïk. İstanbul: Şafak Matbaac1lık.

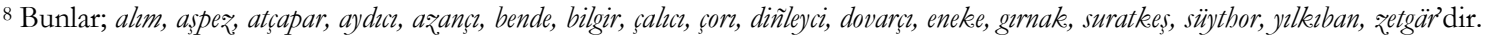


F: fabrikant "fabrikatör", fabrik iş̧̧ileri "fabrika işçileri", farmatsevt "eczac1", farmatsevtika "eczacıllk", futbolçı "futbolcu".

G: garakçı "yağmac1, haydut", garalavçı "savc1, suçlayıc1", garalaycı "boyacı", garavul "bekçi”, garmonçı "armonikac1", gassap "kasap", gassapçllk "kasaplık", geday "dilenci", general "general", generallk "generallik", geñeş̧i "1. ögüt veren öğütleyen. 2. danışman müşavir", gııakegl "müzisyen, gicak çalan", grlyalçı "at yetiştiricisi”, gılyalçllk "at yetiştiriciliğì", grrkımç "kırpma işini yapan kişi, kırpıcı", gırnak "kul, hizmetçi”, gice garavul "gece bekçisi", goragçı "koruyucu", gorayc "koruyucu", goş̧̧ "bekçi, muhafiz", goşunçıllk "askerlik", goyundarçıllk "koyunculuk, koyun yetiştiriciliğ̣i", gönçi "sepici, tabakçı, tabakhane işçisi”, göreşiçi "savaşç1", goșun general "ordu generali", gulluk "görev, hizmet, kulluk", gullukeģ "görevli, memur", guramaç "düzenleyici, organizatör", gvardiyaçı "muhafiz subayı".

H: habarç "1. kararlar1, haberleri, direktifleri halka haber veren, duyuran kimse. 2. gazete ve dergilerde makale veya haber yazan kimse", habarçılı "habercinin yaptığı iş, habercilik", balayık "kadın köle, cariye", bahç "halı dokuyan, hazırlayan usta", halıçllk "halıcılık", halffat "halifelik", halıpa "öğrenciye sanat öğreten, usta, öğretmen", hahpalık "ustalık", halif "halife", halifat "halifelik, hilafet", hammal "taşıyıc1, hamal", hammallk "hamallı", bammalçllk "hamallı", harazman "değirmenci", harbl/dag injineri "maden mühendisi", harbı derñevçi "askeri sorgu yargıcı", harmanç "harmancı", basapç "sayman, muhasip", hasapçllk "saymanlık, muhasiplik", başarç "sulama kanallarını temizleyen, kazan kişi", hatdat "hattat, kaligraf", hatdatllk "hattatllk", häkim "egemen, hakim, hükümdar", hekim "doktor, hekim", heykelçi "yontucu, heykelci",

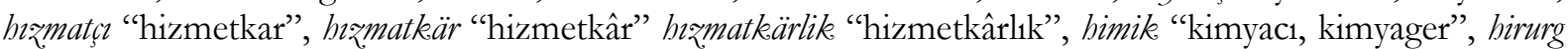
"operatör, cerrah", birurgiya "cerrahi, operatörlük" hocayınlk "1. yöneticilik, başkanlık. 2. hükümdarlık", bokkeygi "hokeyci", bormeyster "1. koro şefinin yardımcisı. 2. operada koro şefi", bökümrovan "egemen, hüküm süren, hakim", bökümrovanlı "egemenlik, hakimlik", hrohikaç "gündelik haberlerle ilgilenen gazeteci", bronolog "kronolog, tarih yazar1, vakanüvis", budojnik "ressam", budojniklik "ressamlk", bücümçi "forvet, ileri saha oyuncusu", bümmetdar "yardımc1, destekçi, hami", bümmetdarlk "yardımc1 olma, destekçilik, hamilik", bünärmenţ̧i "bir işle uğraşan kimse, sanatkar, zanaatçı, esnaf", bünärmentçilik "sanatkarlık, zanaatçll1k, esnaflık", bünkër "hünkar".

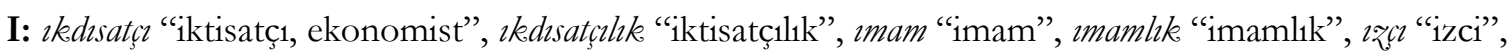
ızçllk "izcilik".

İ: içal "casus", içalı̧ıllk "casusluk", içallllk "casusluk", idedici "bakıc1", idegci "bakıcı", idici "lider, kılavuz", ilçi "elçi", injener "mühendis", inkassator "alımc1, makbuzat memuru", inspektor "müfettiş", instruktor "eğitmen", issgär "işçi".

$\mathrm{J}$ : jandarm "jandarma", jandarmeriya "jandarma kuvvetleri", jivopis "resim, ressamlık", jurnalist "gazeteci", jurnalistika "gazetecilik", jurnalistlik "gazetecilik".

K: kal'kulyator "hesap memuru", kapelmeyster "orkestra şefi", kapitan "yüzbaş1, kaptan", kartograf "haritacı", kassir "kasiyer", kaそ̣ "kadı", kebşirleyci "kaynakçı", keşdeçi "nakkışçı, işlemeci”, keşdeçilik "nakışçlık, işlemecelik", kitaphanaģı "kütüphaneci", kolhoz̧c "kolhozcu", komandir "komutan", komandirlik "kumandanlık", komandirovka "memuriyet, görev", komanduyuş̧iy "kumandan", kombaynçı "kombayn, biçerdöver makinisti", komendant "komutan", komissar "komiser", komissariat "komiserlik", konditer "pastac1, şekerci", konstruktor "proje mühendisi", konsul "konsolos", konsul'tant "danışman, müşavir", konsullk "elçilik", korablñ kapitam "gemi kaptanı", kontrolyor "kontrolcü", kövüsşi "ayakkabıc1", kursant "öğrenci", kümsü̈k "yankesici", kümü̈ş̧i "gümüşçü".

L: laborant "laborant, asistan", leşger "ordu, askerî kuvvetler müfrezesi”, lider "lider, önder, başkan", lotokegl "işportaci".

M: magdancı "madenci", major "majör", maldar "hayvan bakıcısı", malyar "boyacı, badanacı", marşal "mareşal", masgarabaz "palyaço, soytarı", maslahatç "danışman", maşinist "makinist", mayor "binbaşı", mebelçi "mobilyacı", meditsina gullggnnñ kapitan "tıbbî hizmet kaptanı", mergenlike "keskin nişancılık", metallurg "madenci, metalurji uzmanı", ministr "bakan", ministrlik "bakanlı", montyor "montajc1, elektrikçi", motorist "makinist, mugallım "öğretmen", mugallıma "bayan öğretmen", mücevür "mezarlık bekçisi”, müdir "müdür", müfti "müftü", mürze "sekreter, yazıc1, tahsildar".

$\mathbf{N}$ : naçal'nik "başkan", naşal'niklik "başkanlık", nadżiratel "bekçi, gözcü", nakgaşs "1. oymac1, nakkaș. 2. ressam", nakgaşlık "nakkaşlık", namestnik "genel vali", nanbay "firıncı", naturalist "doğa bilimci", navç "1. kayıkç1. 2. kayık ustası", navigatsiya "denizcilik", nebițci "petrol işçisi”, neçcar "dülger, marangoz", nikelleyci "nikelajcı", nilgär "boyacı", nosil'ş̧ik "hamal, taşı1ıcı". 
O: ofitser "subay, zabit", ofitsiant "erkek garson", ofitsiantka "bayan garson", ogrn-cümri "hirsiz", okudicı "öğretmen”, onbaşı "onbaşı", operativ isgär "usta işçi”, operetta "operet”, orakęı "orakç1, ot biçen”, orakul "alc1”, orunbasar "yardımc1, muavin”, oz̧an “ozan, şair”, öñbaş̧ı "önder, öncü, lider”.

P: personal "personel, kadro", pryada "atsız asker, yaya, piyade", pilot "pilot", piyoner"1. öncü, ön ayak olan. 2. komünist çocuk kuruluşlarının üyesi”, poçtal'on "postac1, posta dağıtıcısı", podpolkovnik "yarbay", podpolyeçi "gizli yeraltı mücadelesi yürüten”, polk "albay", poşı "devrimden önce atlı asker", prezident "başkan", professor "profesör", prokuratura "savcll1k", prokuror "savc1", proletar "işçi, proleter", provodnik "kilavuz, rehber, kondüktör".

R: radist "radyotelgrafç", rav "öykücü, hikayeci, hikaye anlatan”, redaktor "düzeltici”, registrator "1. kayıt memuru. 2. daktilo", rejissyor "yönetici, rejisör", rektor "rektör", reportyor "muhabir", rezident "küçük elçi”, ritor "eski Yunan'da konuşma sanatı öğreten kişi", romanist "romanist, Romen dilleriyle uğraşan din bilgini”, ruban "din adami, dine hizmet eden".

S: sagımç "süt sağan kişi, sağıcı", sakı "saki, içki dağıtan”, sanitar "hastabakıcı", sarayman "saray bekçisi”, satıc "satıc1", saz̧ıllk "müzisyenlik", sekretar "sekreter, yazman, katip", sercant "çavuş", sererde "başkomutan, lider”, serhetçi "sinırları koruyan asker”, server “önder, öncü”, sınçı "gözlemci”, siyahatçı "seyyah, gezgin”, skul'ptor "heykelci, heykeltraş”, skul'ptura "heykelcilik, heykel sanatı”, slesar "tesviyeci, çilingir", soldat "asker", sözaydac "kız istemeye giden adam”, spetsialist "uzman, mütehassis", sportsmen "sporcu, sportmen”, starşina "başçavuş”, student "öğrenci”, sud'ya "1. hakim, yargiç. 2. Hakem”, sugunçıllk "geyik yetiştiriciliği", suratçı "ressam”, sukratkeş "ressam”, suvagç "sivacı, s1va yapan”, suvç "sucu, su getiren, su taş1yan, su satan, su veren”, sülçi "sorgu hakimi”, sürüci "sürücü, şoför”, sürümçi "yer süren adam”, süytçi "sütçü, süt satan", süythor "murahabac1, tefeci".

Ş: şah “şah", şahır "şair, ozan”, şahıra "şaire, bayan ozan”, şahırçılk “ozanlık, şairlik", şahırlık "ozanlık, şairlik", şabtaçı "ocakçı, maden ocağ1 işçisi”, şabtyor "ocakç1, maden ocağ1 işçisi”, şaşkaçı "damac1, dama oyuncusu”, şazada "prens, şehzade”, şägirtlik "öğrencilik, çıraklık”, şebird "gece bekçisi”, şef "şef”, şef-povar

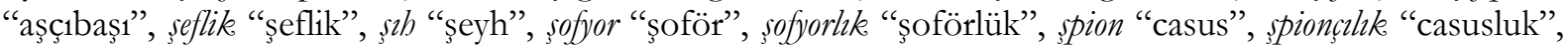
spionlı "casusluk", stangaç "halterci”, stangist "halterci”, streykbreher "grev kiricis1", streykbreherlik "grev kırıcılı̆̆ı", stab ofitseri "kurmay subay", sturman "kaptan", șturmanlık "kaptanlık", ssturvalç "çarkç1, dümenci", sugulçı "ihbarc1, jurnalci, ispiyoncu”, şugulçılı "ihbarcilik, jurnalcilik, ispiyonculuk".

T: talaban "ücretli işçi”, talañçılık "yağmacılık, talancılık", tankıtçı "eleştirmen, tenkitçiı", tapgır "yol gösterici", tarhbsı "tarihçi”, tehnik "teknisyen”, terapevt "iç hastalıkları doktoru, dahiliyeci", terbiyeçi "eğitimci”, tercimeçi "çevirmen", terrorizm "terörizm, teröristlik", tokar "tornac1", topsı "topçu, top atan", trener "çalıştırıc1, antrenör”, tsen₹̧or "sansör, sansürcü”, tsenzorlı "sansürcülük”, tsimbalç "simbalocu”, tsinkografiya "çinkograf”, tsirk artisti "sirk sanatçısı", tsivilist "vatandaşlık hakları uzmanı”, tutaşdırıc "kundakçı".

U: ucreditel "kurucu, tesis eden", ucuc "uçucu, pilot", ucucılı "pilotluk", ucyotçik "muhasebeci", ugradıcı “1. gönderici. 2. Kılavuz”, universal "uzman, kalifiye, işçii”, upravlyayuş̧i "yönetici”, urşucı "savaşç1, döğüşçü”.

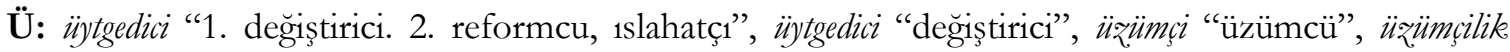
“üzüm yetiştiriciliği, üzümcülük”.

V: vahmistr "çarlık Rusyası'nda süvari başçavuşu”, vahter "odac1", vedomstvo "müdürlük", vekil "temsilci, vekil", vekilcilik "vekillik", vekillik "vekillik, temsilcilik", velosipedçi "bisikletçi”, venerolog "zührevi hastalıkları uzmanı", veteran "eski muharip, gazi”, veterinar "veteriner, veteriner hekimi”, vezir-vekil "vezir vekil", vezirlik "vezirlik", violonçelci "viyolenselci", vitse9-admiral "tüm amiral", vitse-pręident "başkan yardımc1sı", vodolaz. "dalg1ç", vodoprovodçı "su tesisatçısı", vokalist "vokalist", voleybolç "voleybolcu”, voyenkom "askerlik şubesi başkanı", voyevoda "voyvoda", voyevodalık "voyvodalık", vraç "tabip, hekim", vraçlık "tabiplik, hekimlik".

Y: yahtsmen "yatçı", yamşcik "arabac1, faytoncu”, yanamaç "saz çalmayı bilmeyen ancak türkü söyleyen

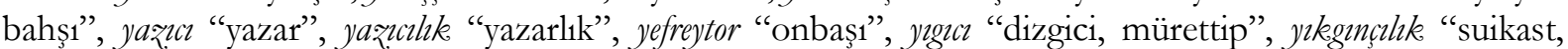
kundakç1lık", yılmaycı "perdah, elmas traşçısı; cilacı", yolagç "seyyah", yolbaşıı "idareci, şef, yönetmen, başkan”, yolçı "yol işinde çalışan, yol işçisi”, yumorçı "mizahçı, mizah yazarı", yuriskonsol't "hukuk müşaviri”,

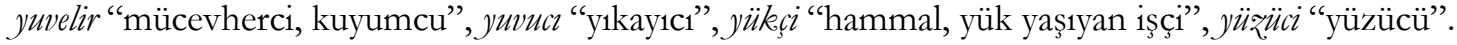

${ }^{9}$ vitse- "yardımcı, muavin" anlamında birleşik sözcük yapar (Tekin, vd. 1995: 666). 
Z: ₹venovod "grup başı, ekip başı", gazeetiñ habarçısı "gazete muhabiri”, yörite habarçısı "özel muhabir", yol görkeęici "yol gösteren, kilavuz, rehber", zetgär "altın ve gümüş işleyen usta, kuyumcu".

Türkmen Türkçesi atasözlerinden derlenen 97 meslek adı ise çalısma alanlarına göre sınıflandırılarak ve etimolojileri verilerek aşağıda gösterilmiştir.

\section{Türkmen Atasözlerinde Geçen Meslek Adlarının Sınıflandırılması}

\section{Tarım ve Hayvancılıkla İlgili Meslekler}

\section{Tarımla İlgili Meslekler}

dayhan "çiftçi" (< dih-gân, dihkan Fa.)

Ankedan suv akar, dayhana Huday bakar. "Arktan su akar, çiftçiye Allah bakar.” (TALD, s. 140)

kärgär "çiftçi" (< kâr-ger Fa.)

Zer gadrm zergär biler, yer gadrm - kärgär. "Altının kıymetini kuyumcu bilir, yerin kıymetini çiftçi." (TALD: 449)

ekinçi “ekinci” (< ek-in+çi)

Kelek geçi ekinçi bolar. "Boynuzsuz keçi ekinci olur.” (TNAS, s. 234)

mellekçi "çiftçi" (< mellek+çi)

Mellekçä yer berseñ, yer eyesini yerden kovar. "Çiftçiye yer kiralarsan, sahibini yerden kovar." (TFMK, s. 55)

Hayvanc1lıla İlgili Meslekler

seyis "at bakıcısı" (< sāyis Ar.)

At mayırmadık, seyis bolmaæ: "At sakatlamadan seyis olunmaz.” (TALD, s.145, TNAS, s. 47)

harban "eşek bakıcısı" (< har-bân Fa.) s. 75)

Zergär zer tanır, harban - har. "Kuyumcu altın tanır, eşek bakıcısı eşek (tanır)." (TALD, s. 449, TFMK,

çarva "göçebe hayvancilık" (< çârpâ Fa.)

Çarvanıñ - yıl gaygısı, serdarin - il gaygısı. "Hayvancilık yapanın y1l kaygisı, hakanın il (vatan) kaygisı var." (TALD, s. 189)

çopan / çofan "çoban" (< çûbân, şûbân Fa.)

Çopan tayagı bir goyun üçin hem göterer, müñ goyun üçin hem. "Çobanın sopası bir koyunu da bin koyunu da güder." (TALD, s. 193, TNAS, s. 99)

Rayat goygun bolsa, çofan köpeler. "Vatandaş koyun olursa, çoban çoğalır.” (TFMK, s. 62)

padıman "sığıı çobanı" (< pâde+men Fa.)

Pada az̧aşmaz, padıman (sı̆ğr çobami) azaşdırar. "Sığır sürüsü yolunu kaybetmez, çoban kaybettirir." (TALD, s. 359, TNAS, s. 287)

\section{Bahçe İşleriyle İlgili Meslekler}

bagban "bağban, bahçıvan" (< bāğ-bān, bāg-vān Fa.)

Çn bagban hem alm, hem zalım. "Hakiki bağban hem alim, hem zalim(dir)." (TALD, s. 191)

\section{Ticaretle İlgili Meslekler}

bakgal "bakkal" (< baḳkāal Ar.)

Baz̧ar görki bakgal, yigit görki sakgal. "Pazarın yakışı̆̆ı bakkal, yiğidin yakışığı sakal.” (TA, s. 116)

bezirgen "tüccar" (< bâzergân Fa.)

Bezirgeniñ gideni bilinmež, geleni bilner. "Tüccarın gideri bilinmez, geliri bilinir.” (TALD, s. 169) 
cerçi “küçük tüccar, dükkan sahibi”' (< ? OT. çar çur 'abur cubur' (DLT) > *çarçu $>$ *çerçü $\left.{ }^{10}\right)$

Cerçiniñ gızı moncuk oynar. "Dükkân sahibinin kııı boncukla oynar." (TNAS, s. 231)

dellal "tellal, simsar" (< dellāl Ar.)

Dellal kem çeker, kelte ölçär. "Tellal eksik tartar, kısa ölçer.” (TNAS, s. 107)

tüçcar"tüccar" (< tuccār Ar.)

Dayhan - kırk yılda, tüçcar - kırk günde. "Çiftçi kırk yılda, tüccar kırk günde.” (TALD, s. 198)

satıc1 / satuvc1 "satıc1" ( $<$ sat-1c1 / sat- $(\mathrm{u}) \mathrm{v}+\mathrm{cl})$

Arzanlıkda ahcomiñ, gimmathkda satıcını̃̃ yü̈z̈̈n görme. "Ucuzlukta alıcının, pahalılıkta satıcının yüzünü görme." (TALD, s. 141)

Arzan bolsa aluvcidan (alcidan) insap gider, gimmat bolsa satuvcıdan (satccidan). "Ucuz olsa alıcıdan insaf gider, pahalı olsa satıcıdan." (TNAS, s. 38)

sövdagär "alışverişçi, satıcı" (< sûdâ-ger Fa.)

Sövdagär azsa, at bilen yarag alar. "Satıcı yoldan çıksa at ile silah alır." (TNAS, s. 303)

zergär "sarraf, kuyumcu" (< zer-ger Fa.)

Är gadırm är biler, zer gardm - zergär. "Yiğidin değerini yiğit bilir, altının kıymetini sarraf bilir." (TALD, s. 231, TNAS, s. 146)

\section{Dinle İlgili Meslekler}

işsan "hoca" (<îşân Fa.)

Gar yagdı diyip begenme-ayaz̨ bardır, işan geldi diyip begenme-nyyazı bardır. "Kar yağdı deyip sevinme ayazı vardır, hoca geldi deyip sevinme niyazı vardır." (TALD, s. 237)

Imam "imam" (< imām Ar.)

Däli däliden hoşlanar, ımam ölüden. "Deli deliden hoşlanır, imam ölüden.” (TALD, s. 201)

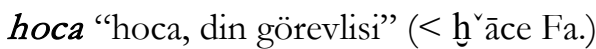

Hocada meshep bolmaz, mollada insap. "Hocada mezhep olmaz, mollada insaf." (TNAS)

molla "molla" (< mollâ Fa.)

145)

At ölse, it şatlanar, bay ölse - molla. "At ölünce it, zengin ölünce molla sevinir (mutlu olur)." (TALD, s.

müftü “müftü” (< muftī Ar.)

Kazısı sö₹lär, müftüsi düzlär. "Kadısı konuşur, müftüsü düzeltir.” (TNAS, s. 234)

\section{Avc1likla İlgili Meslekler}

a vç1 "avc1" (ab+ç1, avç1 ET > av+ç1, awç1 DLT > aw+ç1 KB)

Avçı et iyer, atım it iyer. "Avc1 et yer, atını it yer." (TALD, s. 152, TA, s. 26, TNAS, s. 51)

balıkçı "balıkçı" (< balık+çı)

Balıkçı balıg ilki suv bulanderpt, onsoñ avlar. "Balıkçı balığı önce suyu bulandırdıktan sonra avlar." (TALD, TNAS)

\section{Denizcilikle İlgili Meslekler}

gämiçi1" "gemici" (< kämi+ci EUTS)

Gämä münüp, gämiçi bilen dava etme. "Gemiye binip, gemici ile kavga etme.” (TALD, s. 252)

\footnotetext{
${ }^{10} \mathrm{KBS}$, s. 232.

${ }^{11}$ kemi, kimi: gemi. DLT, s. 702-720.
} 
gayıkç11 "kayıkçı" (< gayık+çı)

Gämiçi gelende, gayıkçı gaçar. "Gemici geldiğinde kayıkçı kaçar.” (TA, s. 67)

Taşımacılık ve Yardımcı Hizmetlerle İlgili Meslekler

hammal "hamal, küfeci" (< ḥammāl ${ }^{13}$ Ar.)

Hammala arkahgr yük bolmaz: "Hamala arkalığı yük olmaz." (TALD, s. 285)

gul "köle" (hul, kul, kul ET > kul DLT > kul KB) 170)

Bidövletiñ ogl bolyançañ, dövlettiniñ gul bol. "Yoksulun oğlu olacağına zenginin kölesi ol." (TALD, s.

gapıçı "kapıc1" (< kapug+çı KB)

Gapıçını̃̃ garn dok (Gapıçmin garn dok, öz öyünde yüzi yok.) "Kapıcının karnı tok, kendi evinde yüzü yok." (TNAS, s. 154)

işçi "işçi” (1ş+çı DLT > iş + çi KB)

Müñ işçiden bir başç. "Bin işçiden bir başçı." (TNAS, s. 256)

aylıkçı "aylıkla çalışan kimse, aylıkçı" ( $<$ ay $+\mathrm{l}_{1} \mathrm{k}+$ çı)

Aylıkçınıñkı ayda tükener, günlükçiniñki günde. "Aylıkçınınki ayda biter, günlükçününki günde." (TNAS, s. 56)

günlükçi "günlükçü” (< gün+lük+çi)

Ayllkscmiñke ayda tükener, günlükçiniñki günde. "Aylıkçınınki ayda biter, günlükçününki günde." (TNAS, s. 56)

Ev Hayatıyla İlgili Meslekler

hizmatkär "hizmetkâr" (< hidmet+kār Ar.+Fa.)

Hizmatkärden ayal bolmaz: "Hizmetkârdan kadın olmaz." (TNAS, s. 210)

\section{Sağl1kla İlgili Meslekler}

lukman "hekim" (< lukmân Ar.)

Lukmanıñ alac etmedigini Eæravlliñ dergäbinde agtar. "Doktorun çare bulamadığını Azrail'in kapısında ara." (TALD, s. 324, TNAS, s. 247)

emçi $1^{14}$ "doktor, tabip" (äm+çi EUTS > em+çi DLT > em+çi KB)

Gün düsyän öyde emçiniñ işi yok. "Güneş giren evde doktorun işi yok." (TALD, s. 281)

hekim "hekim, doktor" (< hekīm, hakīm Ar.)

Halvan hekim iyer, şalgamı-yetim. "Helvayı hekim yer, şalgamı yetim.” (TALD, s. 285)

tebip "doktor, tabip" (< tabîb Ar.)

Dertli gutulcak bolsa, tebibi dus geler. "Dertli iyileşecek olsa doktora rastlar." (TALD, s. 201)

\section{Yöneticilikle İlgili Meslekler}

serdat "hakan, lider, öncü" (< ser+dâr Fa.)

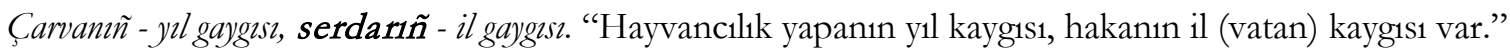
(TALD, s. 189)

soltan "sultan, padişah" (< sulțān Ar.)

\footnotetext{
12 kayg1k, kayguk: kayık. DLT, s. 695.

13 ḥaml (Ar.): yük.

$14 \mathrm{em}$ : ilaç, merhem.
} 
Dilden gelen elden gelse, bar gedaylar soltan bolardı. "Dilden gelen elden gelse, fakirlerin hepsi sultan olurdu." (TALD, s. 203)

hökümdar"hükümdar" (< hükm+dār Ar.+Fa.)

Hökümdars1z ve hekimsiz yurtda oturma. "Hükümdars1z ve hekimsiz yurtta oturma." (TNAS, s. 209)

başçı "baş, lider" (baş+çı KB)

Gögermedik ekinden yer örtener, oñmadık başçıdan il. "Yeşermeyen ekinden yer bikar, düzelmeyen liderden halk.) (TNAS, s. 177)

beg "bey” (bäg ET > beg bēg DLT)

Ilini sılan - beg bolar. "Halkını sayan bey olur." (TALD, s. 307)

beglik"beylik" (bäg+lig ET > beg+lik DLT) 356)

Öz- özüne beglik eden özüne gulluk eder. "Kendi-kendine beylik eden kendine kulluk eder.” (TALD, s.

han "hükümdar, han, padişah" (< hân Fa.)

Han azsa, iline deger, ayal azsa - ärine. "Han (hükümdar) azsa iline (zararı) değer, kadın azsa erkeğine." (TALD, s. 285, TA, s. 75, TNAS, s. 201)

patısa "padişah, hükümdar" (< pād+şāh Fa.) 187)

Çaga bökümi patısa höküminden artıkdır. "Çocuğun hükmü padişahın hükmünden fazladır.” (TALD, s.

şa / şah "şah, padişah" (< şāh Fa.) 332)

Müsürde şa bolandan, Kenganda geda bol. "Misır'da şah olacağına, Kenan'da fakir (dilenci) ol.” (TALD, s.

Müsürde (Misirde) şah bolanindan, Kenanda (vatanda) geday bol. "Misırda şah olmaktansa, Kenan'da (vatanda) dilenci ol." (TFMK, s. 57)

şalık"şahlık" (< şāh+lık Fa.+T.)

Salık hą̣ına dolmagı bilmez: "Şahın hazinesi dolmak bilmez." (TALD, s. 386)

vezir"vezir" (< vezMr Ar.)

Emiriñ bihabarlgı, veziriñ hyyanatı döılet ynkar. "Emirin habersizliği, vezirin hiyaneti devlet y1kar." (TNAS, s. 136)

\section{Adaletle İlgili Meslekler}

kazı "kadı" (< kāạ̣ $\mu$ Ar.) 106)

Davagäriñ kazı bolsa, dadiña Alla yetişsin. "Davacın kadı olursa yardımına Allah yetișsin." (TNAS, s.

cellat"cellat" ( $<$ cellād Ar.)

Beg buyrar, cellat keser. "Bey emreder, cellat keser." (TNAS, s. 75)

\section{Eğitim Öğretimle İlgili Meslekler}

alım "âlim, bilgin" (< âlim Ar.)

Alım öldi, ılım öldi. “Alim öldü ilim öldü.” (TALD, s. 137)

halipa "kalfa, ikinci usta, usta" (< haliffe Ar.)

Halipasız ussa bolmaz, tagsırsız. - molla. "Üstatsız usta olmaz, günahsiz molla olmaz." (TALD, s. 284) 
okuvç1 "öğrenci” (< ok+u-v + ç1 $\left.^{15}\right)$

Okacak bolsañ, okuvçı tapın. “Okuyacaksan, öğrenci bul.” (TNAS, s. 268)

şägirt “öğrenci, kalfa, çırak” (< şâgird Fa.)

Sägirt bolmadık, halıpa-da bolmaz: "Öğrenci (çırak) olmayan, öğretmen (usta) olmaz.” (TALD, s. 387)

Haberleşme, İletişim ve Diplomasiyle İlgili Meslekler

dilmaç "tercüman, dilmaç" $(<\mathrm{t}$ ll+maç $\mathrm{KB})$

Dilmaç öz cogabın özi tapar. "Tercüman kendi cevabını kendi bulur.” (TNAS, s. 114)

ilçi “elçi” (äl+çi, ilçi ET > il+çi KB)

Yaramaz ilçi yamanlık getirer, akıllı ilçi - amanlık. "Kötü elçi kötülük getirir, akıllı elçi esenlik." (TALD, s. 427)

ulag "ulak" (ulag EUTS > ulag DLT)

Garındaşın yamanlaniñ cezasın il berer, ulagını yamanlaniñ cezasın yol berer. "Akrabasını kötüleyenin cezasını halk verir, ulağını kötüleyenin cezasını yol verir.” (TA, s. 16)

\section{Su İşleriyle İlgili Meslekler}

mirap "bir şehrin su işlerine bakan kimse" (< mîr-âb Fa.)

Atañ mirap bolsa da (bolandan), yeriñ oy bolsun (Atañ mirap bolandan, yeriñ pes de bolsun.) "Baban mirap olsa da yerin alçak olsun.” (TNAS, s. 44)

\section{Sanatla İlgili Meslekler}

şahır "şair" (< şā ir Ar.)

Batırñ üstüne batır gelse, battrlıg zaya, şahıriñ üstüne şahır gelse, şahırlgg zaya. "Kahramanın üstüne kahraman gelirse kahramanlığı gider, şairin üstüne şair gelirse şairliği gider.” (TA, s. 31)

oyunç1 "oyuncu” ( $<$ ōy- $\left.(\mathrm{u}) \mathrm{n}+\mathrm{cu}^{16}\right)$

Oyunçı utulamın bilse yagsı. "Oyuncu yendiğini bilse iyi." (TNAS, s. 273)

darbaz"cambaz" (< dâr-bâz Fa.)

Ikki darbaz bir yüpde oynamaz: "İki cambaz bir ipte oynamaz.” (TALD, s. 301)

\section{Esnaf ve Zanaatkârlıkla İlgili Meslekler}

ussa / usta "usta” (< üstâ, üstād Fa.)

Iss köp - kömür az, ussa köp - demir az: "İş çok kömür az, usta çok demir az." (TALD, s. 309)

Usta ber de eliñ çek, molla ber de diliñ çek. "Ustaya ver de elini çek, mollaya ver de dilini." (THEH, s. 42)

ökde: "usta"

Ökde ökdäni görende, ayag1 tibirdep. "Usta ustay1 görünce ayağ1 titrer.” (TALD, s. 347)

Gıda ve Beslenmeyle İlgili Meslekler

degirmençi17 “değirmenci” (< tek- 'dönmek'+ -ir- 'döndürmek, çevirmek'+ men 18+çi)

Her kimiñ bir derdi bar, degirmençiñ derdi suv. "Herkesin bir derdi var, değirmencinin derdi su." (TALD, s. 291)

$$
\text { gassap "kasap" (< ḳașṣāb Ar.) }
$$

Gassap tanısına süyek berer. "Kasap tanıdığına kemik verir.” (TALD, s. 244)

\footnotetext{
15 KBS, s. 620.

16 KBS, s. 644.

17 tägirmän (EUTS) > tegirmen (DLT). EUTS, s. 231; DLT, s. 866.

${ }^{18}$ KBS, s. 272.
} 
yagçı "yağcl" (< yağ+c1)

Yagçı yagdırar, kayı gaydırar. "Yağcı yağdırır, kayı kaydırır." (TNAS, s. 344)

Giyim ve Tekstille İlgili Meslekler

ädikçi1" "edikçi, ayakkabıcı" (etük+çi DLT > etük+çi KB)

Ädikçiden gulaç boyı gaç, demirrsiden - golça boyı. "Ayakkabıcıdan kulaç boyu kaç, demirciden kol boyu (kaç)." (TALD, s. 230)

başmakçı / paşmakçı "ayakkabıc1" (< baş+(m)ak $\left.+c_{c ̧}{ }^{20}\right)$

Başıña düssse, başmakçı bolarsiñ. "Başına gelirse, kunduracı bile olursun.” (TFMK, s. 26)

Başa düssen paşmakçı bor. "Başa düşen (gelen) başmakçı olur." (TALD, s. 160)

tikinçi / dikinçi "terzi, dikişçi” (< tik-(i)n+çi)

Tikinçiniñ yaragı - iñ̃e bilen sapagl. "Terzinin silahı iğne ile ip.” (TALD, s. 395, TA, s. 128)

Yetimlikeden bay bolsa, ayran bermez içmäge, dikinçiden bay çıksa, gaysı bermez biçmäge. "Yetim zengin olsa ayran vermez içmeye, terziden zengin çıksa, makas vermez biçmeye.” (TNAS, s. 371)

\section{Günlük Hayat / Ev Eşyası Aletleriyle İlgili Meslekler}

küyzegär "çömlekçi”" (< kûze-ger Ar.+Fa.)

Ya küyzegär batar, ya dümegär. "Ya çömlekçi batar ya ekin eken.” (TNAS, s. 353)

odunç1 "oduncu" (odun+çı < otuñ EUTS, DLT)

Odunçı gözi omçada. "Oduncunun gözü ağaçta (kütükte).” (TALD, s. 338, TA, s. 111, TNAS, s. 263)

\section{Güvenlikle İlgili Meslekler}

sakçı "nöbetçi, bekçi”" (< sak+ç1 KB)

Gavun sakçı tükeder. "Kavunu bekçi tüketir." (TALD, s. 245) s. 76)

Han yanında sakçıñ bolsa, gara yerde gämiñ yörär. "Han yanında bekçin olursa, karada gemin yürür.” (TA,

dervazçı "kaleci, kale nöbetçisi, kapı muhafızı" ( $<$ dervâze+çi Fa.+T.) 157)

Garr dervazçı dara çıkanda ukusı tutar. "Yaşlı kaleci darağacına çıtı̆̆ı̆ında uykusu gelir." (TNAS, s.

goşç1 "bekçi” (< koş+ç121)

Nesibe baş̧̧, bĩ gosç1. "Kader baş, biz bekçi." (TALD, s. 335)

nöker "nöker, muhafız" (< nöker Moğ. ${ }^{22}$ )

Bayñ̃ başına gul yeter, begiñ başına nökeri. "Zenginin başına kölesi yeter, beyin başına muhafızı." (TNAS, s. 73)

garavul "bekçi”" (kara- 'bakmak' + gul > kara-vul Moğ. ${ }^{23}$ )

Durnadan garavul goysañ, depäñden gıkıllk, gitmez: "Turnadan bekçi koysan, başından gürültü gitmez." (TNAS, s. 124)

\section{Askerlikle İlgili Meslekler}

mergen "atıc1, okçu, nişanc1" (< mergen Moğ.)

\footnotetext{
19 ätük: edik, ayakkabı, terlik, çizme. EUTS, s. 78; etik, etük: pabuç, edik, mest, çizme. DLT, s. 648-649

${ }^{20} \mathrm{KBS}$, s. 120.

21 TDES, s. 429.

22 TDES, s. 496.

${ }^{23} \mathrm{KBS}$, s. 466; ÖTS, s. 2426
} 
Mergen avda belli, geplemsek - davda (davada, cencelde). "Nişancı avda belli olur, geveze tartışmada." (TNAS, s. 252)

\section{Binicilikle İlgili Meslekler}

çapıksuvar "at yarışçısı, cokey" (< çâüuk-süvâr Fa.)

At oglan (çapıksuvar) eşegi hem çapar. "At oğlan (Jokey) eşeği de koşturur.” (TFMK, s. 23)

\section{Madencilikle İlgili Meslekler}

demirçi “demirci” (tämir+ci EUTS > temür+çi DLT > temür+çi KB)

Demirçiniñ atı nalsız, ädikẹiniñ-ädigi. "Demircinin atı nalsız, ayakkabıcının çizmesi." (TA)

\section{Sporla İlgili Meslekler}

pälvan "pehlivan" (< pehlevân Fa.)

Gaharm yuwdan -pälvan. "Kahrını gizleyen pehlivandır." (TA, s. 88)

böke "pehlivan" (< böke Moğ. ${ }^{24}$ )

Yıkılsañ-da bökeden yıkıl. "Yenilirsen de pehlivana yenil." (TFMK, s. 73)

\section{Dilencilikle İlgili Meslekler}

geday "dilenci" (< gedâ Fa.)

Gedaya borçl bolma, ya toyda dilär, ya bayramda. "Dilenciye borçlu olma, ya düğünde ister ya bayramda" (TALD, s. 248)

gedayçıllk "dilencilik" (< gedâ+çı+lık Fa.+T.+T.)

Gedayçıllga da gurp gerek. "Dilenciliğe de güç gerek." (TNAS, s. 167)

gedaylık "dilencilik" (< gedâ+lık Fa.+T.)

İssiz̨lik ya gedaylgga elter, ya-ogruluga. "İssizlik ya dilenciliğe iter, ya da hırsızlığa." (TA, s. 82)

dilegçi “dilenci” (< dile-g+çi) 113)

Dilegçiniñ garm doysa-da, gözi doymaz: "Dilencinin karnı doysa gözü doymaz." (TA, s. 51, TNAS, s.

\section{Falc1lıkla İlgili Meslekler}

palçı "falcı" (< fâl+çı Ar. + T.)

Palçı yalançı. "Falcı yalancı." (TALD, s. 359, TNAS, s. 287)

\section{Meşru Olmayan Meslekler}

galtaman "eşkıya, çapulcu" (< ḳaltebān Fa.)

Galtaman garrasa yalançı bolar, bürgüt garrasa - sıçançı. "Çapulcu (eşkıya) yaşlansa yalancı olur; kartal yaşlansa sıçancı olur." (TALD, s. 236)

garakçı "haydut, yol kesen, eşkıya" (<gara-k+çı)

Garakçı topardan ayrlam sancar. "Haydut gruptan ayrılanı yakalar." (TALD, s. 238)

ogrt25 "hirsız" (ogrn EUTS > ogr1 DLT)

Ognñ̃ yol bir, kovgiñ yol yüz: "Hırsızın yolu bir, izlemenin (yakalamanın) yolu yüz.” (TALD, s. 342)

İl ogrusız bolmaz, dag - börïiz: "Ülke hirsızsız olmaz, dağ kurtsuz.” (TALD, s. 306, TFMK, s. 51, TA, s. 146)

ogurlik "hırsızlık" (<og(u)r-u+lik)

\footnotetext{
${ }^{24} \mathrm{KBS}$, s. 172.

25 ogr1, ogru $<\operatorname{og}(u) r-1$.
} 
Oglanl öyde ogurllk yatmaz: "Oğlanlı evde hırsızlık olmaz.” (TALD, s. 340)

Ogurlk eden uyalmaそ, üstüne gelen uyalar. "Hirsılık eden utanmaz, üstüne gelen (yakalayan) utanır)." (TALD, s. 343)

ogrulik "hirsılık" (<ogr1+lik DLT)

Ogrulık eden uyalmaそ, üstüne gelen uykalar. "Hırsızlık eden utanmaz, hırsızllğı suçüstünde yakalayan utanir." (TALD, s. 342)

\section{Müzikle İlgili Meslekler}

dovulçı "davulcu" ( $<$ țabl+çı Ar. + T.)

Gız̨a erk berilse, ya dovulça barar, ya surnayşa. "Kıza güç (kendi hâline bırakılsa) verilse, ya davulcuya ya zurnaciya varır." (TALD, s. 257)

surnayçı "zurnac1" (< surnây+ç1 Fa. +T.)

Nagara döveniñ surnayçıdan habar bar. "Davul çalanın zurnacıdan haberi yok." (TNAS, s. 259)

bagş126 "türkücü, saz şairi, halk ozanı” (< bahşi, bakșs EUTS) s. 289)

Her işiñ hayr yagssıdr, toyuñ bęegi bagşıdır. "Her işin hayrı iyidir, dügünün süsü türkücüdür." (TALD,

Bagşıñkı bay bilen, mollañkı vay bilen (gę̧er). "Ozanınki hay ile, hocanınki vay ile (geçer)." (TFMK, s. 25)

\section{Eğlence Hayatıyla İlgili Meslekler}

orramsı "fahişe" (< rūspī Fa.)

Ogr hem özüne osar, orramsı hem. "Hırsız da kendini haklı görür, fahişe de." (TFMK, s. 58)

celep "fahişe" (< celeb Fa.)

Bosagası altından bolsa da, celep beley yene de almut islär. "Eşiği altından da olsa fahişe kadın yine de hakkını ister." (TNAS, s. 90)

\section{Sonuç}

Türkmen atasözlerinde aynı meslek adının ses değişikliğine uğramış şekilleri hariç toplam 97 meslek adı tespit edilmiştir. Atasözlerinde geçen meslekler dışında Türkmence sözlüklerden ise 460 meslek adı derlenmiştir. Bu sayıya atasözlerinde rastlanılan meslek adları dâhil değildir.

Meslek adlarının en fazla geçtiği gruplar yöneticilik, ticaret, taşımacılık ve yardımcı hizmetler, güvenlik, hayvancılık ve tarımdır. Bu gruplarda yöneticilikle ilgili 11, ticaretle ilgili 8, taşımacılık ve yardımcı hizmetlerle ilgili 6 , tarımla ilgili 4, güvenlik ve hayvancılıkla ilgili 5 meslek adı bulunmaktadır. Türkmen atasözlerinde diğerlerine nazaran bu grupların ön plana çıkmasının sebebi yine atasözleri üzerinden mesleklere yönelik sosyo-kültürel açıdan yapılacak bir çalışmayla daha iyi açıllanabilir.

Türkmen atasözlerinde Türkçe kökenli 34 meslek adı belirlenmiştir. Kökeni Türkçe olanlar dışında Farsça 27, Arapça 18, Farsça+Türkçe 4, Farsça+Türkçe+Türkçe 1, Arapça+Türkçe 2, Arapça+Farsça 3, Moğolca 4 meslek adı saptanmıştır.

Aynı zamanda eski Türklerin kullandığı meslek adlarından bir kısmı aynen ya da bazı farklılıklarla Türkmencede yaşamaktadır. kadr: kazı $(\mathrm{KB})>$ kazı $(\mathrm{TkmT})$, kapııı: kapugçı $(\mathrm{KB})>$ gapıçı (TkmT), avçı: abçı, avç1 (ET) > avçı, awç1 (DLT) > awç1 (KB) > avç1 (TkmT), ayakkkabıcı: etükçi (DLT) > etükçi (KB) > ädikçi $(\mathrm{TkmT})$ vb.

Türkmen Türkçesinde meslek adları türetilirken en çok + çi ve +lik yapım ekleri kullanılmıştır. Atasözlerinde isimden isim yapan +çi ekiyle türetilmiş 35 meslek adına rastlanırken aynı görevdeki +lik ekiyle türetilen 5 meslek adına denk gelinmiştir. Bunların dışında fiilden isim yapan -1c1 (satıc1) ve -vc1 (satuvcı) ekleriyle birer meslek adı belirlenmiştir. 
Türkmen atasözlerinde bazı mesleklerin birden fazla adla karşılandığı dikkati çekmiştir. Örneğin; çiftçi sözcüğü için dayhan, kärgär ve mellekçi olmak üzere 3 ayr1 ad kullanılmıştır. (doktor: lukman, hekim, emçi, tebip; usta: ökde, ussa, usta; pehlivan: pälvan, batır, böke; öğrenci: okwvç, şägird; satıc1: satcr, satuvcl, sövdagär, tüccar: be zirgen, tüccar vb.).

Aynı adlı meslekler arasında ise küçük ses değişiklikleri bulunduğu gözlenmiştir. Terzi anlamına gelen tikinçi/dikinci ile çoban anlamındaki çofan/çopan bu durumu örnekleyen sözcüklerdir.

Ayrıca Türkmence deyimlerdeki meslek adlarına da bakılmış fakat atasözlerindeki kadar kayda değer bir sonuç elde edilemediğinden çalışmaya dâhil edilmemişlerdir. Deyimler için Mehmet Kara ve Ahmet Karadoğan'ın hazırladığı "Türkmen Türkçesi-Türkiye Türkçesi Deyimler Sözlügü̆” adlı kitap taranmıştır. Bunun sonucunda Türkmence deyimlerde, atasözleri arasında bulunmayan sadece 2 meslek adı belirlenmiştir. Bunlar; "yayık işçisi, yağcı" manasındaki cuvaz̧ı (< cuvaz+çı Fa.+T) ve "yüklenici, müteahhit" anlamında kullanılan potratçı sözcükleridir.

cuvaz̧ıñ erkeği yalı "bir yerde dolanıp duran, gözü bağlanmış gibi hiçbir yere gidemeyen -insan için."

potraţ̧ı bolmak "toptan çalışmak."

Deyimler arasında atasözleriyle ortak olan meslekler geday ve garavuldur. Geday gezmek deyiminin aynı zamanda dilencilik mesleğini anlatmak için kullanıldığı görülmektedir.

geday gezmek "kapı kapı dolaşarak dilenmek, dilencilik etmek."

garavula almak. "1. nişan almak, gezlemek. 2. gözlem altına almak."

\section{Etik Beyan}

“Türkmen Atasözlerinde Meslek Adları" başlıklı çalışmanın yazım sürecinde bilimsel, etik ve alıntı kurallarına uyulmuş; toplanan veriler üzerinde herhangi bir tahrifat yapılmamış ve bu çalışma herhangi başka bir akademik yayın ortamına değerlendirme için gönderilmemiştir.

\section{Kaynakça}

Ercilasun, A. B. ve Akkoyunlu Z. (2018). Dîvânu Lugâtit'-Türk (Giriş-Metin-Ceviri-Notlar-Dižn). Ankara: TDK Yayınlar1.

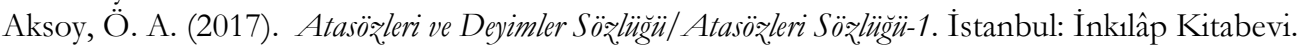

Arat, R. R. (1947). Kutadgu Bilig I Metin (3. Bask1). Ankara: TDK Yayınları.

Azmun, Y. (1966). Türkmen balk edebiyatı hakkenda. Reşid Rahmeti Arat İçin. Ankara: Türk Kültürü Araştırma Enstitüsü Yayınlar1. ss. 32-83.

Beydili (Memmedov), C. (2004). Atalar söæü̈. Bakü: Önder Neşriyat.

Caferoğlu, A. (1968). Eski Uygur Türkesesi sözllïgü. İstanbul: Edebiyat Fakültesi Basımevi.

Çeneli, İ. (1986). Türkmen türkçesi sözlügüu. Türk Dili Arasttrmalar Yulluğ̌-Belleten, 26(1982-1983), 29-84.

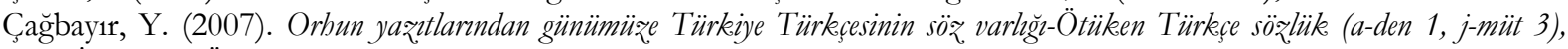
İstanbul: Ötüken Neşriyat.

Çınar, A. A. (1996). Türkmenistan halk edebiyatı türleri. Türk Dünyast Dil ve Edebiyat Dergisi, 2, 353-370.

Devellioğlu, F. (2010). Osmanlica-Türkse ansiklopedike lügat. Ankara: Aydın Kitabevi.

Dilçin, D. (2000). Edebiyatımı̨da atasö:leri. Ankara: TDK Yayınları.

Doğan, L. (2014). Türkmen atasözleri (Türkmen nakellar). İstanbul: Parafiks Yayınevi.

Eyüboğlu, İ. Z. (1998). Türk dilinin etimoloji sözliuğüi. İstanbul: Sosyal Yayınları.

Geldiyev, G. ve Altıyev, A. (2002). Türkmen Nakıllar ve atalar sǫ̈̋i. Ankara: Atatürk Kültür Merkezi Başkanlığ1 Yayınları.

Gülensoy, T. (2007). Türkiye Türkcesindeki Türkse sözcü̈klerin köken bilgisi sözlügüi-Etimolojik sözlük denemesi- (I-II). Ankara: TDK Yayinları.

Güner, G. (2010). Kıpçak Türkçesindeki meslek adları üzerine içerik ve yapı bakımından bir sınıflandırma denemesi. Turkish Studies, 5(3), 1416-1448.

Güneş, B. (2016). Kutadgu Bilig'deki meslek ve unvan adlarının derleme sözlüğü’ne yansımaları. Uluslararası Türkşe Edebiyat Kültuir Eğitim Dergisi, 5(4), 1532-1543.

Kilıç, M. (1996). Türkmen atasözleri-Türkmen folklorr. Bursa: Özsan Matbaacilık.

Kara, M. ve Karadoğan, A. (2014). Türkmen Türkesesi-Türkize Türkęesi deyimler sözlliğ̈ü. İstanbul: Etkileşim Yayınları.

Kürenov, S. ve Gümüş, M. (1995). Türkmen atasöZleri. Ankara: Engin Yayınevi.

Şen, S. (2007). Orbun, Uygur ve Karahanl metinlerindeki meslekler bağlammda eski Türk këlltuirü (Doktora Tezi). On Dokuz Mayıs Üniversitesi, Sosyal Bilimler Enstitüsü, Samsun.

Tekin, T. vd. (1995). Türkmence-Türkse söəlük. İstanbul: Şafak Matbaacilik.

TDK (2005). Türkse sözllïk. Ankara: TDK Yayınları. 
Tez, Z. (2016). Meslekler taribi (Eski çağlardan günümüz̨ zanaatsal ve sanatsal uğraşlar). İstanbul: İnk1lâp Kitabevi.

\section{Kisaltmalar}

Eser Kisaltmaları

TALD: Türkmen Atasözleri (Türkmen Nakılları)

TNAS: Türkmen Nakılları ve Atalar Sözi

TFMK: Türkmen Atasözleri-Türkmen Folklor1

TA: Türkmen Atasözleri

THEH: Türkmen Halk Edebiyatı Hakkında

EUTS: Eski Uygur Türkçesi Sözlüğü

DLT: Dîvânu Lugâti't-Türk

KB: Kutadgu Bilig

ÖTS: Orhun Yazıtlarından Günümüze Türkiye Türkçesinin Söz Varllğı-Ötüken Türkçe Sözlük

KBS: Türkiye Türkçesindeki Türkçe Sözcüklerin Köken Bilgisi Sözlüğü -Etimolojik Sözlük Denemesi

TDES: Türk Dilinin Etimoloji Sözlüğü

\section{Dil Kısaltmaları}

ET: Eski Türkçe

TkmT: Türkmen Türkçesi

TT: Türkiye Türkçesi

Azr.: Azeri Türkçesi.

T.: Türkçe

Fa.: Farsça

Ar.: Arapça

Moğ.: Moğolca

\section{EXTENDED ABSTRACT}

Oral literary products are a tool in order to see to what extent the Turkish people, who are scattered across different geographies in the world, maintain and sustain their cultural and moral values in cultural terms. They are also ideal for identifying names that are specific to a field. These are the products that are produced by the people and have a national character. However, each type of oral literature has its own characteristics.

The fact that the Turkmens had a late transition to written literature provided them consolidate many products of the oral field. Turkmen folk literature which is a separate value in this respect is a treasure in terms of the proverbs, idioms, folk songs, songs and fairy tales.

Proverbs in Turkmen oral literature are called "nakıl". Between the proverbs of the Turkmen Turkish and Turkey Turkish, there are partnerships in terms of meaning, subject and form. This partnership will be seen better when we exemplify it from both languages with a proverb. Tkm'T Bir akmagin guya atan

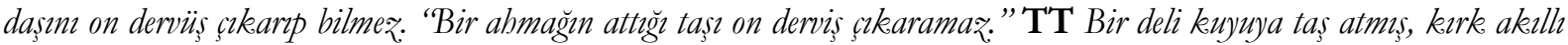
çkaramamıs.

Turkmen Turkish is located in the eastern arm of the Turkish dialects of the Oghuz group (SouthWest). In this study, based on the proverbs of Turkmen Turkish, professions specific to Turkmens were revealed. As knows, professions have an important place in human life. People need to work and have a profession in accordance with the requirements of their lives Professions within the scope of economic activities emerged with the existence of human beings and has been diversified to the present day in accordance with the needs of people. In this respect, the professions of a society are a precursor of the political, social and economic life of the society, just like oral literature products. 
Professions compiled from Turkmen proverbs are classified under a total of 25 main topics according to their fields of study and then the name which origin is certain is listed next to the language in which it passes. In this way, it is tried to determine what foreign languages are at the forefront in Turkmen Turkish vocabulary.

In Turkmen Turkish, the name of the "profession" is met with the words bünär, kär, kesp, senet. There are some similar or same words between the profession names obtained from the Turkmen proverbs the professions in the Old Turkish Period, Dîvânu Lugâtiât-Türk and Kutadgu Bilig.

For example; In Turkmen, the word "emci" means doctor. This profession name is derived from Turkish languages' derivational affix "+çi" "em" which is means "drugAforementioned word encountered in EUTS as "ämçi", in DLT and KB encountered as "emçi" which used in the Turkmen. Again in EUTS as "tämirci", in DLT and KB as "temürçi" in the form of the name of the profession encountered that the sound of " $\mathrm{t}$ " at the beginning of the word turns into "d" (demirci) in Turkmen. As seen in the two examples we have shown here and in the study where we give many examples in the separate section, except for some sound changes, there is a similarity in the names of professions.

In this study, except the proverbs, as well as the profession names in Turkmen dictionaries, were also expressed by scanned. However, they were not included in the studyUnlike proverbs, it was noted that there were professional names composed of two words in dictionaries scanned. Some of them are as follows: "dermanhana isgäri: pharmacist, et satcc: butcher, birca dellall: stockbroker, yol görkezici: guide, ayakgap garalaycl: shoeshine, bicimci ayal: switchman girl, batrak ayal: capstan women, gice garavull: watchman, yörite habarçst private correspondent, cogapkar nobatcl: responsible guard". The majority of these vocabulary names are in the form of adjective and indefinite noun phrase. In addition to these, there are also profession names in the form of dilemma as "ogr-cümri: horsı̌, vezir-vekil: vezir vekil".

As a result, in the Turkmen proverbs 97 pieces and in Turkmen dictionaries 460 pieces profession names were reached. The presence of such profession fields shows that Turkmens are active and effective in social and economic terms.

In addition to the words of Turkish origin, identifying the name of the profession from other languages as Persian 27 pieces, Arabic 18 pieces, Mongolian 4 loan reveals that Persian and Arabic languages are more effective in the Turkmen vocabulary.

It is seen that the most "+ ç" derivational affix of Turkish language is used in the names of professions mentioned in the Turkmen proverbs. As in Turkey Turkish, in Turkmen Turkish, this affix is to nominalize the name of the profession by adding to the names. Also, derivational affix of "lik" in the same task is among the attachments used in the construction. On the other hand, since it was added to the verbs, there was an profession name derived from the "1c1" and "vc1" appendices in a separate category.

Finally, there are examples in Turkmens where profession is met with at least two and at most four names. However, this does not apply to every profession. For example, the words mentioned in Turkmen proverbs as "lukman, hekim, emçi, tebip" means "doctor". There are only minor phonetic differences some are among the same profession names (cofan/çopan $v$ b.). 